\title{
Why Do Only Males of Mawia benovici (Pelagiidae: Semaeostomeae: Scyphozoa) Seem to Inhabit the Northern Adriatic Sea?
}

\author{
Valentina Tirelli ${ }^{1, *(D)}$, Tjaša Kogovšek ${ }^{2}$, Manja Rogelja ${ }^{3}$, Paolo Paliaga ${ }^{4}$, Massimo Avian ${ }^{5}$ and Alenka Malej ${ }^{6}$ (D \\ National Institute of Oceanography and Applied Geophysics_OGS, 34151 Trieste, Italy \\ Independent Researcher, Strunjan 125, 6320 Portorož, Slovenia; jellygist@gmail.com \\ 3 Aquarium Piran, Academic, Electronics and Maritime High School, Bolniška 11, 6330 Piran, Slovenia; \\ manja.rogelja@gmail.com \\ 4 Faculty of Natural Sciences, University of Pula, 52100 Pula, Croatia; paolo.paliaga@unipu.hr \\ 5 Department of Life Science, University of Trieste, Via L. Giorgieri 10, 34127 Trieste, Italy; avian@units.it \\ 6 Marine Biology Station Piran, National Institute of Biology, Fornače 43, 6330 Piran, Slovenia; \\ alenka.malej@nib.si \\ * Correspondence: vtirelli@inogs.it
}

check for

updates

Citation: Tirelli, V.; Kogovšek, T.; Rogelja, M.; Paliaga, P.; Avian, M.; Malej, A. Why Do Only Males of Mawia benovici (Pelagiidae: Semaeostomeae: Scyphozoa) Seem to Inhabit the Northern Adriatic Sea?. Diversity 2021, 13, 222. https:// doi.org/10.3390/d13060222

Academic Editor: Bert W. Hoeksema

Received: 10 May 2021

Accepted: 19 May 2021

Published: 21 May 2021

Publisher's Note: MDPI stays neutral with regard to jurisdictional claims in published maps and institutional affiliations.

Copyright: (c) 2021 by the authors. Licensee MDPI, Basel, Switzerland. This article is an open access article distributed under the terms and conditions of the Creative Commons Attribution (CC BY) license (https:// creativecommons.org/licenses/by/ $4.0 /)$.

\begin{abstract}
This manuscript presents four new observations of the jellyfish Mawia benovici in the Adriatic Sea. This new species was recently identified as Pelagia benovici by Piraino et al. (2014) and then placed in the new genus Mawia by Avian et al. 2016. This species is rare and is almost exclusively observed in the Adriatic Sea. Interestingly, the majority of observations refer to males only. Few studies have addressed the issue of sex determination in Syphozoa in particular, as sex identity can only be determined at the medusa stage. Unfortunately, the rarity of M. benovici and the lack of female specimens have so far prevented indispensable laboratory studies to clarify its life cycle. Still, we tried to propose an explanation for our field observations.
\end{abstract}

Keywords: jellyfish; sex ratio; Mediterranean Sea

The jellyfish Mawia benovici (Piraino, Aglieri, Scorrano, \& Boero, 2014) represents a real mystery for marine biologists because, just as it appeared out of nowhere in 2013, it disappeared just as quickly [1].

This new species was first identified as Pelagia benovici [2], was classified in the holoplanktonic genus Pelagia (Peron \& Lesueur, 1810), and was therefore expected to lack a polyp stage. However, based on molecular differences with other pelagiid genera and a detailed analysis of fine morphological features, Avian et al. [1] showed that P. benovici belongs to the new genus Mawia Avian, Ramšak, Tirelli, D’Ambra \& Malej, 2016, which seems to be most closely related to genus Sanderia Goette, 1886. Unfortunately, the rarity of this species and the paucity of female specimens have so far prevented the necessary laboratory studies to clarify its life cycle.

To date, this new species has been rarely observed and is almost exclusively located in the Adriatic Sea [1-3] with the exception of some specimens collected from the shore near Dakar (Senegal) [4] and a dense jellyfish aggregation that emerged at the entrance of Igoumenitsa Bay (Ionian Sea) in June 2018 [5]. Here, we report about four new observations of Mawia in the northeastern Adriatic Sea. A specimen of M. benovici (Figure 1A) was sampled from the coast in Piran (Slovenia) $\left(45.53^{\circ} \mathrm{N}, 13.56^{\circ}\right.$ E) on 18 December 2018. It was maintained for a few hours in an aquarium for observations and photography, after which it was sacrificed for measurements and sex determination. The specimen had a bell diameter of $7.2 \mathrm{~cm}$ and wet mass of $28.61 \mathrm{~g}$, and it was a male. At the end of 2020, one specimen of $M$. benovici was observed near Rovinj $\left(45.06^{\circ} \mathrm{N}, 13.64^{\circ} \mathrm{E}\right)$ surrounded by dozens of ctenophores Mnemiopsis leidyi A. Agassiz, 1865 on 27 November and again on 
1 December (Figure 1B,C). A month later (27 December 2020), one specimen was captured in front of the Piran Aquarium $\left(45.53^{\circ} \mathrm{N}, 13.56^{\circ} \mathrm{E}\right.$ ) (Figure 1D-F). Unfortunately, in 2020, no additional morphological observations were made. The specimens collected in Piran on 27 December were photographed while it was maintained in an aquarium for a couple of hours before being released back to the sea. Its photographs (Figure 1E,F) show details of gonads presenting the typical ivory coloration observed in males of this species [1].
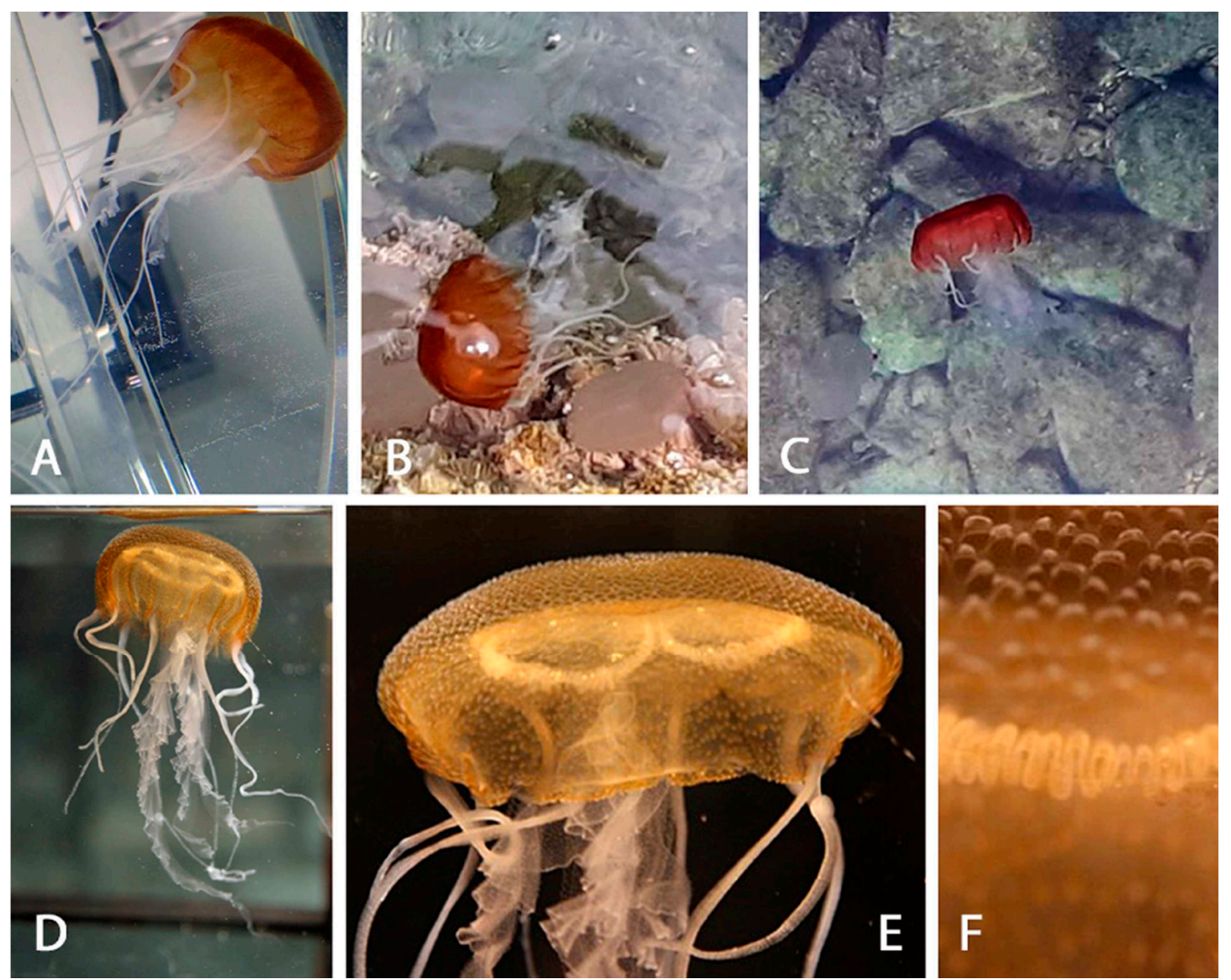

Figure 1. Recent observations of Mawia benovici in the Adriatic Sea: (A) Bay of Piran (Slovenia) on 18 December 2018; (B,C) near Rovinj (Croatia) on 27 November and 1 December 2020, respectively: in these images, Mawia benovici is surrounded by Mnemiopsis leidyi ctenophores; (D) in front of the Piran Aquarium on 27 December 2020; (E) detail of the umbrella of the specimen in (D); and (F) magnification of the gonadic ribbon of specimen in (D).

Except for one female described by Piraino et al. [2], M. benovici specimens found in the Adriatic Sea and inspected for sex have been exclusively males (Avian et al. [1]; over 25 unpublished observations, the specimen captured in Piran in December 2018, and probably also the one collected on 27 December 2020). Moreover, Bayha et al. [4] suggested the western coast of Africa as the possible source of this species but it is still unclear if M. benovici should be considered a non-native species in the Mediterranean Sea. If the species has been introduced in the Adriatic Sea, as suggested by Piraino et al. [2] and Bayha et al. [4], transport in ballast waters and/or fishing practices appear to be the most probable vectors of transmission for this jellyfish. We speculate that polyps and/or their offspring rather than medusae were transported. Scyphozoan polyps survive extreme conditions far better than medusae, and the latter are not likely to survive the de-ballasting process.

The vast majority of scyphozoans are gonocoric with a medusa male/female ratio varying around 1:1, and polyps or their clones always produce medusae of one sex only [6]. The genets, i.e., sexually produced genetic individuals, stably maintained their sex throughout their lifetime $[7,8]$. That being the case, the almost exclusively male medusae found in the Adriatic Sea could originate from a predominantly male polyp population that might have been established in the northern Adriatic Sea. Moreover, combined phylogenetic 
analyses [1] indicated that the genus Mawia was most closely related to genus Sanderia. Schiariti et al. [9] and Avian et al. [10] showed that Sanderia malayensis Goette, 1886 uses a multi-mode polyp reproduction strategy, producing motile particles and planuloids, and they reported the highest reproduction rates ever found for a scyphistoma under laboratory conditions for this species [9]. If $M$. benovici has similar reproductive modes, even a small number of introduced polyps attached to ships' hulls and/or other motile reproductive particles possibly transported in ships' ballast waters could have established a viable polyp population in the Adriatic Sea.

Author Contributions: Conceptualization, V.T. and A.M.; writing-original draft preparation, V.T., T.K., M.A., and A.M.; investigation: T.K., M.R., and P.P. All authors have read and agreed to the published version of the manuscript.

Funding: Tjaša Kogovšek was funded by the Ministry of Higher Education, Science, and Technology of Slovenia (contract "Raziskovalci-2.0-NIB-529024" (C3330-17-529024)), and Alenka Malej was funded by the Research Core Founding No. P1-0237, Slovenian Research Agency.

Institutional Review Board Statement: Not applicable.

Informed Consent Statement: Not applicable.

Data Availability Statement: All data generated during this study are included in this article.

Acknowledgments: The authors would like to thank Stefano Piraino for his constructive comments on the first draft of this manuscript.

Conflicts of Interest: The authors declare no conflict of interest. The funders had no role in the design of the study; in the collection, analyses, or interpretation of data; in the writing of the manuscript; or in the decision to publish the results.

\section{References}

1. Avian, M.; Ramšak, A.; Tirelli, V.; D’Ambra, I.; Malej, A. Redescription of Pelagia benovici into a new jellyfish genus, Mawia, gen. nov. and its Phylogenetic Position within Pelagiidae (Cnidaria: Scyphozoa: Semaeostomeae). Invertebr. Syst. 2016, 30, 523-546. [CrossRef]

2. Piraino, S.; Aglieri, G.; Martell, L.; Mazzoldi, C.; Melli, V.; Milisenda, G.; Scorrano, S.; Boero, F. Pelagia benovici sp. nov. (Cnidaria, Scyphozoa): A new jellyfish in the Mediterranean Sea. Zootaxa 2014, 3794, 455-468. [CrossRef] [PubMed]

3. Yokes, M.; Andreou, V.; Bakiu, R.; Bonanomi, S.; Camps, J.; Christidis, G.; Crocetta, F.; Giovos, I.; Gori, A.; Juretić, T.; et al. New Mediterranean Biodiversity Records (November 2018). Med. Mar. Sci. 2018, 19, 678.

4. Bayha, K.M.; Collins, A.G.; Gaffney, P.M. Multiple phylogeny of the scyphozoan jellyfish family Pelagiidae reveals that the common U.S. Atlantic sea nettle comprises two distinct species (Chrysaora quinquecirrha and C. chesapeakei). Peer J. 2017, 5, e3863. [CrossRef] [PubMed]

5. Chartosia, N.; Anastasiadis, D.; Bazairi, H.; Crocetta, F.; Deidun, A.; Despalatović, M.; Di Martino, V.; Dimitriou, N.; Dragičević, B.; Dulčić, J.; et al. New Mediterranean Biodiversity Records (July 2018). Med. Mar. Sci. 2018, 19, 406-407. [CrossRef]

6. Tardent, P. Sex and Sex Determination in Coelenterates. In Intersexuality in the Animal Kingdom; Reinboth, R., Ed.; Springer: Berlin/Heidelberg, Germany, 1975; pp. 1-13.

7. Siebert, S.; Juliano, C.E. Sex, Polyps and Medusae: Determination and Maintenance of Sex in Cnidaria. Mol. Reprod. Dev. 2017, 84, 105-119. [CrossRef] [PubMed]

8. Liu, C.; Gu, Z.; Xing, M.; Sun, Y.; Chen, S.; Chen, Z. Sex determination and differentiation in Aurelia sp.1: The absence of temperature dependence. J. Oceanol. Limnol. 2018, 36, 457-464. [CrossRef]

9. Schiariti, A.; Morandini, A.C.; Jarms, G.; von Glehn Paes, R.; Franke, S.; Mianzan, H.W. Asexual reproduction strategies and blooming potential in Scyphozoa. Mar. Ecol. Progr. Ser. 2014, 510, 241-253. [CrossRef]

10. Avian, M.; Motta, G.; Prodan, M.; Tordoni, E.; Macaluso, V.; Beran, A.; Goruppi, A.; Bacaro, G.; Tirelli, V. Asexual reproduction and strobilation of Sanderia malayensis (Scyphozoa, Pelagiidae) in relation to temperature: Experimental evidence and implications. Diversity 2021, 13, 37. [CrossRef] 